\title{
Problems of Islamic Home Financing in Indonesia: A Tawhidi String Relation (TSR) Exposition
}

\author{
Bambang Wijanantoํㅜ, Yuswar Zainul Basri², Akhmad Affandi Mahfudz³, \\ Akhmad Suraji ${ }^{4}$
}

\begin{abstract}
This study intends to explore and analyze Home Islamic financing problems in Indonesia by using the Tawhidi String Relations (TSR) approach, a methodology that uses the Quran and Sunnah as ontology in each solution to variables in achieving wellbeing. TSR has advantages over the concepts of Interaction, Integration and Evolution (IIE). The variables of this study are Human Resources, Internal Controls and Regulators, who represent internal and external interests. This study found that the IHF problems must be overcome by the concept of changing religious values into economic activities referring to the Quran and Hadith which are presented practically in the real world as a universally applicable basis in achieving Maqasid Sharia.
\end{abstract}

Keyword: Islamic home financing, Tawhidi String Relation, maqasid sharia

Abstrak. Penelitian ini bermaksud untuk menggali dan menganalisis permasalahan Pembiayaan Syariah Rumah Tangga di Indonesia dengan menggunakan pendekatan Tawhidi String Relations (TSR), suatu metodologi yang menggunakan Alquran dan Sunnah sebagai ontologi dalam setiap solusi variabel dalam mencapai kesejahteraan. TSR memiliki keunggulan dibandingkan konsep Interaksi,Iintegrasi dan Evolusi (IIE). Variabel penelitian ini adalah Sumber Daya Manusia, Pengawas Internal dan Regulator, yang mewakili kepentingan internal dan eksternal. Studi ini menemukan bahwa permasalahan HKI harus diatasi dengan konsep mengubah nilai-nilai agama menjadi kegiatan ekonomi yang mengacu pada Alquran dan Hadits yang disajikan secara praktis di dunia nyata sebagai landasan yang dapat diterapkan secara universal dalam mencapai Maqasid Syariah.

Kata Kunci: Pembiayaan Rumah Syariah, Tawhidi String Relation, maqashid syariah

1 Universitas Trisakti Jakarta | bawie99@gmail.com (Corresponding Author)

2 Universitas Trisakti Jakarta | yuswarzainulbasri@gmail.com

${ }^{3}$ Universitas Darussalam Gontor | affandi@unida.gontor.ac.id

4 Uinversitas Andalas, Padang | akhmad.suraji@gmail.com 


\section{Introduction}

The concept of human needs in an Islamic perspective will lead to maslahah (welfare). Human needs are commensurate with the desires determined by the satisfaction parameters of consumer behavior as elements in maqasid sharia (sharia objectives), namely the achievement of human welfare. Therefore, all goods and services that have maslahah are said to be human needs. One of them is the home as a basic need to reach the maslahah. Every goal of sharia is maslahah, whether in the form of achieving benefits, or avoiding mudharat, the substance of maqasih sharia is maslahah (Sahroni \& Karim, 2017). According to Imam Syatibi in (Syarifuddin Amir, 2008) classifies 3 (three) tiered human needs namely dharuriyat (primary needs), hajiyiah (secondary needs) and tahsiniah (tertiary needs). The home is part of the needs of dhahuriat which involves the needs of human life as one of the means of achieving maqasih sharia.

The home is a place for human life in treading the dynamics of life, both in joy and sorrow. The home becomes an essential basic need for humans in finding and fulfilling inner and outer life with sakina (full of calm), peaceful and provides a comfortable atmosphere. The dream home is able to support His servants to draw closer to Allah Subhanahu Wa Ta'ala. Home too becomes a strategic thing in shaping the character and personality of a person, the values of a family, where the home becomes a space to express all efforts and ways to live life through interactions and activities with all family members. As Rasulullah Shalallaahu 'Alayhi Wasallam in the prophetic story said "Baiti jannati", that the home for a Muslim in addition to functioning as a residence, also functions as a place of education (tarbiayul aulad), as a shelter. Rasulullah Shalallaahu 'Alayhi Wasallam made his home a place to nurture his friends and from that home was born a generation of rabbani who became the best people. 
The need to own a home is a dream for everyone, therefore everyone strives to have a home. However, the more expensive the price of a home is inversely proportional to the limited economic capacity of buyers, the activity of buying a home is mostly done by credit (installments) through conventional banks and Islamic Commercial Banks (ICB). Sharia Home Ownership financing products through banks develop along with the development of population growth and growing community needs for housing. One of the interests of Muslims to buy a home through ICB is based on the factor of one's religiosity because there is a problem there (Alam et al., 2012). In another study said that the variables of attitude, perceived behavioral control, religious obligations and religiosity are positively correlated with the intention to use Islamic personal financing (Abdullah, Safiah, \& N, 2014). Increased awareness of Muslims to deal with ICB both in the context of saving, using services and proposing personal and business financing, becomes an interesting phenomenon and it is appropriate for the majority of Indonesia's population to be subjects and objects in participating in developing the Islamic financial industry growing rapidly.

The types of IHF contracts that are popular in Indonesia are Murabahah, Musyarakah Muntanaqisah (MMQ) and Ijarah Muntahia Bii Tamlik (IMBT), and are dominated by Murabahah and MMQ, whose portfolios reach 89\% (OJK, 2019). On the other hand, there are still many phenomena that arise in the field in the implementation of IHF contracts. Murabahah financing is still similar to the interest system, without changing the substance, although the mechanism and terms of the contract have fulfilled Islamic principles, but the determination of margin still uses the interest determination component like conventional banks (Marwini M, 2015). Chong \& Liu (2009) stated that the method of Islamic financing is still close to conventional financing, ICB is still considered no different from conventional banks because it still uses an interest basis.

Sugeng (2014) states that Murabahah financing has many problems in its implementation, including; in determining the margin is still based on the time 
value of money and considering the level of risk over a period of time, the margin is still expensive compared to conventional financing because as long as the tenor margin is fixed, while financing with interest often fluctuates lower as a reference interest rate falls, in practice there is no real sales from ICB to customer, by documentation and recording of assets have never been recorded at ICB (imperfect documentation aspects), and there are still late fees that are still imposed. Studies in Malaysia show that only a small portion of Islamic bank financing is truly PLS (profit loss sharing) based and that Islamic deposits are not interest free, but are strongly linked to conventional savings (Chong \& Liu, 2009). IHF is not appropriate to be used in Islamic banks, because it tends to practice usury (riba) like conventional banks (Marwini M, 2015).

Mahfudz, et al. (2016) said that IHF still faces problems in settling sharia rental prices and other problems such as determining the right sharia contract to underpin product structuring in the MMQ contract. Regarding rental rates, many empirical studies have addressed this issue without reaching any resolution because the dispute is mixed with many interpretations and to date no consensus has been reached by the parties involved, including jurists, practitioners and users of Islamic law. One reason is that many Islamic banks still prefer to use interest as a benchmark because it generates more profit than the proposed Islamic rental rate.

Ascarya (2015) examined the low cost of P / L (profit sharing) financing of sharia banks in Indonesia, by grouping them into two aspects of the root of the problem, namely the internal aspects of Islamic banks, which include top management, human and technical resources, and external aspects include the community, authorities and customers. The results showed that internal problems had shifted from human resources to technical aspects (Technology Information/IT and Standard Operating Procedure/SOP) and top level management (commitment). 
Some problems related to the implementation of financing agreements on ICB have been classified by the OJK in the Murabahah Product Standards Book, and the Musharakah Product and MMQ Product Book, into 3 (three) main issues, namely: sharia issues, legal issues and operational issues (OJK, 2015). Islamic Financial Institutions must be able to ensure that all transactions follow the rules of sharia (sharia compliance), not only in the format and legal formalities but far more important in the economic substance which is the goal of sharia namely the achievement of maslahah (Isra, 2011) .

This research was conducted qualitatively with the aim of expounding essential issues related to the problematics of Islamic Home (IHF) and as well as analyzing some of the causes through the TSR approach. Research on IHF is interesting and important to study because the home is a basic human alphabet that is everyone's dream and has a large portfolio on the ICB. The problem of IHF is inseparable from the condition of sharia banks in general that there are currently many inhibiting factors including human resources, cultural development and entrepreneurial spirit (entrepreneurship) that is still weak, relatively limited capital, the ambivalence between the concept of sharia ICB management with the reality on the ground, the level of public trust in ICB is still low, and academically has not been formulated comprehensively related to systematic and proportional development (Rusydiana, 2016).

\section{Literature Review}

Muslims really need financing instruments that are free from usury, gharar and maisir, because basically Muslims understand that usury is detrimental and makes the economy unstable. As Allah's warning in the Quran about usury that is forbidden including written in the letter Ali Imron [2] : 30 and An Nisa [4] : 161, Al Baqoroh [2] : 275, whereas God has justified the sale and purchase, as stated in in An Nisa [4] : 29 and also in the hadiths of the Apostles too many commercial 
teachings and examples. The main reason for customers who choose IHF is the agreement runs according to sharia and is expected to provide peace and blessing.

Previous research discussing problems and related to IHF issues has been widely reviewed by many authors. Isu et al. (2017) said that deviations in the practice of murabahah contract, which resulted in the contract being vanishing sharia, among others; (1) Violation of murabahah terms, namely ownership requirements for assets (milkiyah) and the known initial price (ra'sul mal ma'lum), and (2) Placement of murabahah contracts on wrong transactions. MMQ is a fair concept between banks and customers, but there are other issues that still need to be explored, including when payment failures and responsibilities of each party (Zainan \& Ismail, 2013).

Gholamreza Zandi, (2012) states the murabahah contract in Iran, and Malaysia still uses the conventional principle of the bank, which is actually prohibited. In practice in Malaysia, Islamic banking is not much different from conventional banking, only a small portion of Islamic bank financing is truly PLSbased (profit loss sharing) and that Islamic deposits are not interest-free. Chong \& Liu, (2009).

Rusydiana (2016) states there are 4 factors that arise in the development of Islamic banks in Indonesia, namely: HR, technical, legal / structural aspects, and market / communal aspects. Raharjo, (2011) stated that another matter which was a deviation in the quality and capability of Islamic banking, and caused the impact of Shariah Compliance, was the presence of prominent business interests from the board of directors related to company profit (profit) being the main indicator in business progress and improvement. Ascarya (2008) states in his research that Regulators are still limited in providing supportive regulation and incentives. Rusydiana \& Hasib (2019) in their research stated that the criteria of the most priority influencing customers in choosing an Islamic bank in Indonesia is the service and factors of religiosity or the suitability of banks with sharia principles. 
The rental structure for MMQ requires a more Islamic formula, which includes risk risks, overhead costs and profit margins, which are expected to replace interest rates and base lending rates (Mahfudz, 2016). Regulatory obstacles in MMQ financing are also an immediate obstacle that is anticipated, related to the disharmony of positive legal regulations and their muamalat fiqh in implementation (Abubakar \& Handayani, 2017). Alam et al. (2016) highlighted non-compliance with sharia requirements when carrying out MMQ contracts, which are recommended to revaluate property values to their fair values, especially in termination of contracts and annual periodic reviews, must share all related costs in the contract. In accordance with their respective shares.

Osmani \& Abdullah (2010) MM (Musyarakah Mutanaqisah) has many advantages over the BBA, but in order to be more in line with sharia principles, several legal rules relating to Islamic banking contracts, taxes and land ownership need to be modified. Ben Salah Mahdi \& Boujelbène Abbes (2018) states that based on Islamic and conventional banks, it is evident that banks having high targets tend to show risk aversion behavior, while banks that are not oriented towards high targets. Kurniawan, Afit Inayah, (2014) stated that there was a mismatch between the positive principles of Islamic law that had been applied in the Murabahah, IMBT and MMQ contracts.

Related to sharia compliance parameters, Rosly (2010) states that in order for shariah compliance to be implemented well, there are 4 important factors that must be applied in a package, namely factors based on the approach; Covenants, Financial Statements, Legal Documents and Maqasid Sharia. Components that play a role in maintaining compliance are the role of the Sharia Supervisory Board (DPS) based on research Faozan (2013) states the role of DPS in implementing good corporate governance at Islamic banks includes controlling, assessing and supervising activities at Islamic financial institutions to ensure compliance with sharia principles and rules. DPS must also disseminate and educate the public through media in the community such as the sermon and majlis ta'lim. 
Waluyo, (2017) said that the Islamic Bank's commitment to the adoption of the National Sharia Council fatwa was not yet effective and efficient. The results showed that the fatwa related to Islamic banks that had been transformed into positive law could be used as a legal basis for compliance.

This research conceptually explored \& analysed the problem of IHF with the TSR approach, focused on internal and external interests, to formulate solutions towards the maslahah (wellbeing).

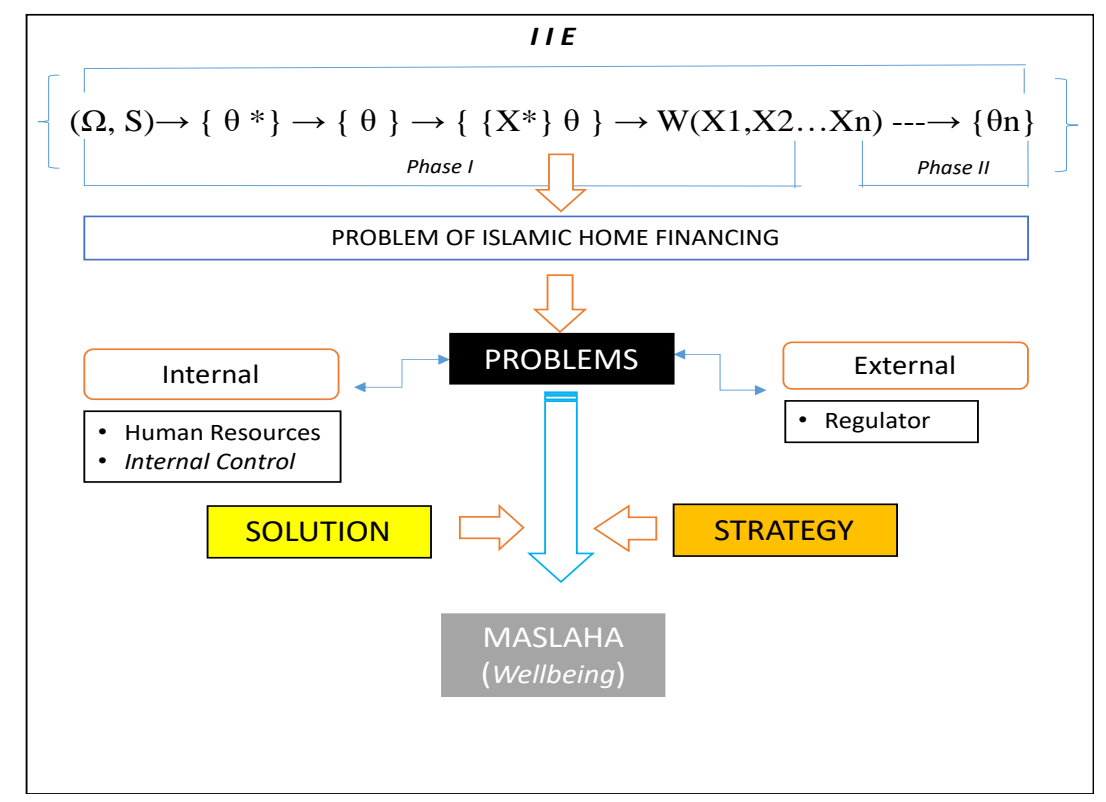

Figure 1. Framework

\section{Methods}

The research was conducted with a qualitative approach by exploring through the study of literature and describing the problems of IHF by employing TSR approach. The TSR method was chosen due to the IIE concept (Interactive, Integrative and Evolution), where the variables influence each other and give feedback / circular to each other to reach the solution.

According to Choudhury (2007) TSR is a methodology that originates from monotheism, or monotheism for the Essence of Allah SWT which revealed the Quran $(\Omega)$ as the main source and the beginning of all science (primordial of 
knowledge), which is Kalam Allah, has absolute nature, including comprehensive life, therefore cannot be added or subtracted. The Quran teaches general principles, Rasululloh implements His verses in daily life as an As Sunnah or Al Hadith (S) which is also the next source of knowledge. Al Qur'an and As Sunnah can be elaborated in law by using epistemological deduction or withdrawing the general principles contained in these sources to be applied in the reality of individual life.

In TSR theory, wellbeing is achieved if the resources that are owned can be utilized properly based on the rules of the Quran and Sunnah as the ontology of a theory of Tawhidi String Relations (TSR). The Tawhidi methodology is considered as an endogenous driving factor of learning and moral awareness in obtaining wealth. As a result, recognition of the Tawhidi methodology that underlies the acquisition of all material things shows the permissible wealth criteria. Islamic law considers personal and social wealth in the same way as individuals and society and thereby characterizes what should and should not be considered as recommended wealth (Choudhury, 2012) .

Choudhury (2007) notes that Islamic banks have mushroomed under the Islamic agenda, but have not developed a comprehensive vision with an interestfree system, and also do not mobilize financial resources in order to improve social welfare by promoting economic development in Islamic lines. This omission, according to him, was shared more generally through Islamic economic and social thinking which did not produce a Koranic view and had failed to understand the dynamics of Islamic transformation in a fair and participatory framework. But Choudhury envisions the function of social welfare for Islamic banks between social security, protection of individual rights and resource mobilization in accordance with Islamic beliefs.

Islamic banks as agents of development must play a role in the welfare of the community by facilitating IHF through sharia-compliant contract products. The problem of implementation in the field shows the phenomenon of sharia 
violations whose causes can occur from various problems from internal and external factors, which will be interesting to explore through the TSR concept.

Maqasid sharia is derived from the word maqshad and maqashid which is derived from the root word qashd. Maqasid shows the plural word which means goal or target. Every maqasid (objective) in sharia maqasid is a benefit in the form of benefits achieved or mudharat that is avoided, so the substance of sharia maqasid is maslahah (Sahroni Oni. \& Adiwarman, 2017). Benefits (maslahah), in this case, means everything that concerns human sustenance, fulfilment of human life, and acquisition what is demanded by their emotional and intellectual qualities, in the absolute sense (Rama, A., 2013). Maqasid sharia is the basis for the establishment of Islamic law and its application, both in the areas of worship, muamalat and morality (Harahap, 2014). Universally maslahah gives the meaning of the word as wellbeing or common good. Ashur, (2006) defines maqasid as follow: "Deeper meanings and inner aspect of wisdoms (Hikam) considered by the lawgiver in all or most of the areas and circumstances of legislation "

Stressed that the importance of maqasid sharia knowledge is not only in textual understanding and interpretation, but also in finding solutions to new problems facing Muslims. (Nugroho, Hidayah, \& Badawi, 2018) show relationship between maqasid sharia and maslahah below:

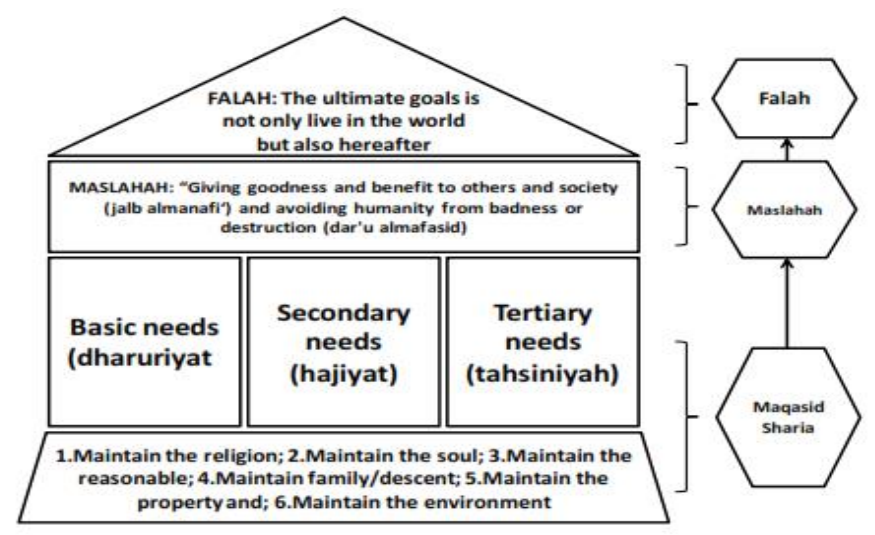

Figure 2. Maqasid Sharia And Maslahah

Source : Nugroho, Hidayah, \& Badawi, 2018 
Based on a literature study, this study is intended to explore many problems that still occur by focusing on the issue of Human Resources (HR) aspects, and Internal Control, as part of Internal aspects and Regulators which are external aspects. HR, Internal Control and regulators are important aspects in carrying out IHF, HR as an actor who executes financing, based on rules and systems that have been set, while Internal control is part of the operational supervision system based on DSN fatwa and OJK rules, while the regulator (OJK \& DSN) each has complementary responsibilities to regulate and supervise the operations of Islamic Banks.

According to Choudhary \& Hossain (2005), the results of the implementation of laws, policies or decisions based on God's law will produce a life impact which is a blessing from God as rahmatan lil alamin, we symbolize the results of the implementation with the symbol $\left\{\theta,(X){ }^{*}\right\}$.

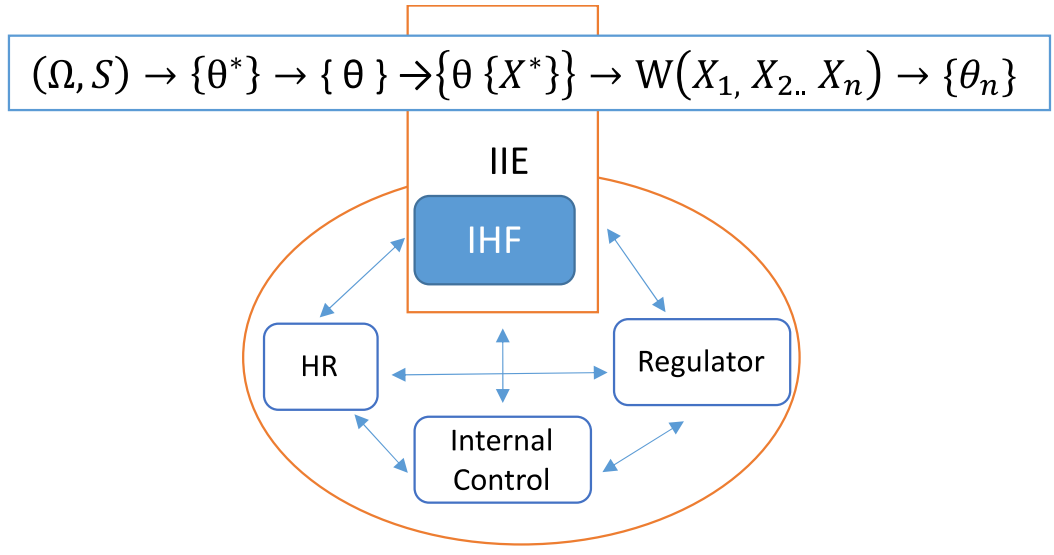

Figure 3. HR, Internal Control and Regulator Source : Author

Explanation as follows: (1) Internal Problems, are problems that occur from within the ICB which consist of aspects of HR and Internal Control, as the follow : (a) HR, is a key person in the management and staff of the bank whose main task is providing IFH financing. (b) Internal Control is a system of operating procedures 
as an internal control tool that functions to oversee ICB operations. (2) External Problems are problems that originate from outside the ICB, which are represented by the Regulator as follow: The regulator is represented by the FSA, is the Financial Services Authority, which is responsible for regulating and overseeing the financial industry, and DSN-MUI, is the National Sharia Council-Indonesian Ulema Council in charge of issuing policies and fatwas related to products and regulations relating to sharia law.

\section{Results and Discussions}

This paper employs library research in surveying some relevant literature to examine issues arising in IHF.

These aspects are variables contained in $\left\{\theta\{X\}^{*}\right\}$ which are described in the TSR formula:

$$
\begin{array}{lll}
(\Omega, S) \rightarrow\left\{\theta^{*}\right\} \rightarrow \theta \rightarrow\left\{\theta\left\{X^{*}\right\}\right\} & \rightarrow \mathrm{W}\left(X_{1}, X_{2 \ldots} X_{n}\right) \rightarrow\left\{\theta_{n}\right\} \\
\Omega \quad: \text { denotes Al Quran } & \theta:: \text { denotes knowledge } \\
S & : \text { denotes Al Hadist } & \mathrm{X}: \text { variable } \\
\left\{\theta^{*}\right\}: \text { denotes I'jma } & \mathrm{W}: \text { wellbeing }
\end{array}
$$

These aspects can be formed in a function model as follows:

Problem of Islamic Home Finance (PHF) is a function of those aspects that interact with each other, integrate and evolve (Interaction, Integration, Evolution / IIE) towards a new balance and reach maslahah (wellbeing) with functions:

PHF $=f\left(X_{1}, X_{2}, X_{3}\right)$

by adding $\theta$, the equation becomes as follows:

$$
\begin{aligned}
& X_{1}(\theta)=f_{1}\left\{\operatorname{PHF}(\theta), X_{2}(\theta), X_{3}(\theta),(\theta)\right\} \\
& X_{2}(\theta)=f_{2}\left\{\operatorname{PHF}(\theta), X_{1}(\theta), X_{3}(\theta),(\theta)\right\}
\end{aligned}
$$




$$
\begin{aligned}
& X_{3}(\theta)=f_{3}\left\{\operatorname{PHF}(\theta), X_{2}(\theta), X_{1}(\theta),(\theta)\right\} \\
& (\theta)=f_{4}\left\{\operatorname{PHF}(\theta), X_{1}(\theta), X_{2}(\theta), X_{3}(\theta)\right\}
\end{aligned}
$$

Equation (2.6) is called the welfare function (W $(\theta)$ ), which is formed from the $\theta$ process that is induced by knowledge. Induction of Knowledge $(\theta)$ into the PHF function, proves the contribution and weight of the aspects and elements in it by interacting, integrating and evolving to find a balance towards wellbeing. PHF together with sequential variables namely HR (X1), Internal Control (X2) and Regulator (X3) interact with each other, are circular caution, independently influence each other and are interdependent between aspects and elements with judgment knowledge that always refers to the Quran and Hadith $(\Omega, S)$ as the main basis sourced from the divine which circularly and dynamically adjusts towards the benefit that is formed.

Induction of knowledge to HR (X1) through faith, good deeds and morals that are maintained makes the foundation of self in carrying out the mandate of work. Divine guidance will always be realized in daily work to feel that work is part of worship. His sharia knowledge can be transformed outwardly into judgment in managing work problems, which refers to the values contained in the Quran and Hadith. The character of shidiq, fathonah, tabligh and amanah must make the pillars to form identity, or in other languages HR must have integrity and professionalism that reflects Islamic attitudes and behavior. Professionalism is an articulation of a fathonah (competent) attitude, while integrity is the principal of a moral attitude (tabligh), accompanied by commitment (amanah), honest (shidiq) and able to do it professionally. That attitude is complete with a trustful attitude towards sharia compliance, so the best solution to the problem of home financing will be obtained. According to Azmy (2015) Islamic banks must have a long-term development strategy in developing human resources, with characteristics of 
shiddiq (true and honest), tabligh (developing the environment / subordinate towards good), trust (trustworthy), and fathonah (competent and professional).

Internal Control (X2) aspects are systems, tools, procedures, operational technical instructions that have been prepared by inducing Islamic spiritual values. This system is a parameter for making compliance tools. The Regulator Aspect (X3) aims to regulate, manage and oversee the implementation of ICB operations so that business relationships remain in a harmonious and harmonious corridor. The regulator as the caliph is God's representative in the world to uphold God's rules that must be obeyed.

According to Budhijana (2012) if we put religious values $(\theta)$ that originate from the Quran and Sunnah $(\Omega, S)$ it will foster and develop the cell nucleus. The nucleus of the cell develops and changes over time. It creates a delicate network that is interrelated and develops strongly and enlarges simultaneously. This is caused by the learning process. Therefore to determine the level of influence of each factor on other factors, a circular causation model is needed.

The function of the above aspects becomes a means to benefit if the intra and inter aspects of interaction are colored by the values of faith and morals. Procurement of homes through IHF makes facilities for customers to have a home in reaching maqasid sharia, HR runs contract trusts with good and professional commitments, Internal Control is used as a parameter in complying with sharia rules, and Regulators carry out the mandate to maintain the Islamic muammalat level, then the maqasid sharia way is open field and stakeholders hopefully towards maslahah life. Yusuf, (2015) states that the development and management of Islamic banks must be in accordance with Islamic Bank standards, because they must meet the Islamic economic philosophy, legal, vision and mission, development policies, and strategies to achieve targets. In addition, HR qualifications must be adequate and rely on the Quran and Sunnah. 


\section{Conclusion}

The problem of IHF must be overcame by the concept of transforming religious values into economic activities. The Quran and Hadith are presented practically in the real world as the basis for the function of Islamic homes financing universally. This value is reflected in honesty, transparency, fairness, free usury, togetherness, and benefit.

Sharia compliance as a parameter for the transformation of Islamic values must be accompanied by commitment and integrity of the stakeholders to carry it out. HR work is based on sharia rules stipulated in the Operating System Procedure, the Sharia Supervisory Board conducts internal control, regulators regulate and supervise from the external side.

In the framework of development and growth of IHF all are integrated through a knowledge-based process (induced knowledge based) which unites the institution's evolution system with all the knowledge parameters as basis. By involving the knowledge base on the process of interaction, integration and evolution, the process dynamically will increases sharia compliance, in order the problem of IHF will reduce and wellbeing can be reached smoothly

Any solution and strategy resulting from the implementation of the knowledge of God in everyday life X $(\theta)$ should always be followed by an evaluation and self-introspection of how far the actualization of the law of God is executed to determine how big the impact of increased blessings for the welfare of human life which is reflected in wellbeing function $W(\theta, X(\theta))$. According to North (1991) and Douglass (1993), in Budhijana et al. (2020) solutions without knowledge will always lead to routine problems and even new problems.

Future studies should add several variables such as Management, IT and customer, so that conclusions are more comprehensive, solutions and strategies are sharper. 


\section{References}

Al Quran Al Karim

Abdullah, N., Safiah;, N., \& N, A. W. (2014). Factors Affecting The Intention to Use Islamic Personal Financing. IJMS, Vol. 22, Special Issue: 47-60.

Abubakar, L., \& Handayani, T. (2017). Telaah Yuridis terhadap Pembiayaan Perumahan Melalui Akad Musyarakah Mutanaqisah (MMQ) Sebagai Alternatif Pembiayaan Perumahan dalam Upaya Pengembangan Produk Perbankan Syariah. Jurnal Hukum Ekonomi Islam, Vol. 1: 194-219.

Ahmad Saifuddin, W., \& Bambang Budhijana, R. (2020). Analysis of Tawhidi String Relation (TSR) Towards Factors that Affect the Distribution of Financing of Sharia Banking in Indonesia Period 2009-2019. SSRN Electronic Journal, (March). https:/ / doi.org/10.2139/ssrn.3548025

Akhmad Afffandi Mahfudz, Nor Hayati Ahmad, Rosylin Mohd Yusoff, Asmadi Muhamad Naim, T. A. (2016). Restructuring Rental Rate Components to be More Innovative Sharia Compliance Product in Islamic Financing. European Journal of Islamic Finance, Vol. 5.

Alam, A., Sori, Z. B. M., Ramadailil, S. M., Anwer, Z., \& Shinai V S. (2016). Musyarakah Mutanaqisah Home Financing; Issue in Practice. Journal of Islamic Accounting and Business Research, Vol. 9(1): 91-103

Alam, Shah, S., Janor, Hawati, Zanariah, Wel, Nilufar, M. (2012). Is Religiosity an Important Factor in Influencing The Intention to Undertake Islamic Home Financing in Klang Valley?, World Applied Sciences Journal. https://doi.org/10.5829/idosi.wasj.2012.19.07.392

Ascarya. (2008). The Lack of Profit-And-Loss Sharing Financing in Indonesia's Islamic Banks : Revisited, 1-15. Review of Indonesian Economic and Business Studies

Ascarya. (2015). Analysis on Financial Crisis and How to Prevent It using the Islamic Perspective., Conference: The 9th International Conference on Islamic Economics and Finance", organized by SESRIC, IRTI - IDB, IAIE, and Hamad bin Khalifa University At: Istanbul, Turkey

Ashur, I. (2006). Teorythis on Maqashid Sharia. Petaling Jaya: Islamic Book Trust.

Azmy, A. (2015). Mengembangkan Human Resource Management yang Strategis untuk Menunjang Daya Saing Organisasi: Perspektif Manajemen Kinerja (Performance Management) di Bank Syariah. Binus Business Review, Vol. 
6(1), 78-90.

Ben Salah Mahdi, I., \& Boujelbène Abbes, M. (2018). Behavioral Explanation for Risk Taking in Islamic and Conventional Banks. Research in International Business and Finance, Vol. 45(February): 577-587. https://doi.org/10.1016/j.ribaf.2017.07.111

Budhijana, R. B. (n.d.). Institutional Factors Affecting Sharia Banking Performance in Indonesia 2000-2011., (Taruma Negara University.).

Chong, B. S., \& Liu, M. H. (2009). Islamic banking: Interest-free or Interest-based? Pacific Basin Finance Journal, Vol. 17(1): 125-144. https://doi.org/10.1016/j.pacfin.2007.12.003

Choudhury, M. A. (2007). The Universal Paradigm and The Islamic World-system: Economy, Society, Ethics and Science. World Scientific, Vol. 57.

Choudhury, M. A. (2012). Reversing Entropy to Sustainability: The Moral Dimension. OIDA International Journal of Sustainable Development, Sultan Qaboos University - College of Commerce \& Economics Date Written: February 6, 2012, Vol. 3, no.

Faozan, A. (2013). Implementasigood Corporate Governance Dan. La Riba Jurnal Ekonomi Islam, Vol. VII: 1-14.

Gholamreza Zandi. (2012). Some Issues on Murabahah Practices in Iran and Malaysian Islamic Banks. African Journal of Business Management. https://doi.org/10.5897/ajbm11.2859

Harahap, Z. A. A. (2014). Konsep maqasid al-syariah sebagai dasar penetapan dan penerapannya dalam hukum Islam menurut 'Izzuddin bin 'Abd alSalam (w. 660 h). TAZKIR: Jurnal Penelitian Ilmu-ilmu Sosial dan Keislaman, Vol. 9(2), 171-190.

Isra. (2011). Islamic Financial System, Principla \& Operation. Kualalumpur: ISRA, International Shari'ah Research Academy for Islamic Finance

Isu, B., Mur, M., \& Ah, Ā. B. A. H.. (2017). Penyimpangan Akad Murābahah Di Perbankan Syariah Dan Beberapa Isu Mengenai Murābahah Oleh: Sofyan Sulaiman. Madania: Jurnal Kajian Keislaman, Vol. 7(1).

Kurniawan, A., \& Inayah, N. (2013). Tinjauan Kepemilikan Dalam KPR Syariah: Antara Murabahah, Ijarah Muntahiyyah Bittamlik, dan Musyarakah Mutanaqisah. Equilibrium, Vol. 1(2). 
Mahfudz, A. A. (2016). Pertinent Issues in Islamic Home Financing. ISRA International Journal of Islamic Finance, Vol. 8(1).

Marwini M. (2015). Aplikasi Pembiayaan Murabahah Produk KPRS di Perbankan Syari 'ah. AL-IHKAM: Jurnal Hukum \& Pranata Sosial, Vol. 8(1): 141.

Nugroho, L., Hidayah, N., \& Badawi, A. (2018). The Islamic Banking, Asset Quality: "Does Financing Segmentation Matters" ( Indonesia Evidence). Mediterranean Journal of Social Sciences, Vol. 9(5). https://doi.org/10.2478/mjss-2018-0154

OJK. (2015). Kodifikasi Produk dan Aktifitas Bank Umum Syariah dan Unit Usaha Syariah.https://OJK.go.id

OJK. (2019). Snapshop Perbankan Syariah. https://OJK.go.id

Osmani, N. M., \& Abdullah, F. (2010). Musharakah Mutanaqisah Home Financing: A Review of Literatures and Practices of Islamic Banks In Malaysia. International Review of Business Research Papers, Vol. 6(2): 272282.

Raharjo, V. (2011). Inovasi Produk Masih Tantangan Bank Syariah: Joint High Level Conference on Islamic Finance, Bank Indonesia (BI) dan Bank Negara Malaysia (BNM), .

Rama, A., \& M. (2013). Pembangunan Ekonomi dalam Tinjauan Maqashid Syariah. Dialog, Vol. 1(1): 31-46.

Rosly, S. A. (2010). Shariah Parameters Reconsidered. International Journal of Islamic and Middle Eastern Finance and Management.

Rusydiana, A. S. (2016). Analisis Problem Pengembangan Perbankan Syariah di Indonesia: Aplikasi Metode Analytic Network Process. Esensi, Vol. 6(2): 237-246. https:/ / doi.org/10.15408/ess.v6i2.3573

Rusydiana, A. S., \& Hasib, F. F. (2019). Islamic Banking Selection Criteria: Case in Indonesia Using Analytic Network Process. Economica: Jurnal Ekonomi Islam, Vol. 6(2): 237-246. https://doi.org/10.21580/ECONOMICA.2019.10.1.2846

Sahroni Oni., \& Adiwarman, K. A. (2017). Maqashid Bisnis \& Keuangan Islam (2nd ed.). Depok Jabar: PT. Rajagrafindo Persada Depok.

Syarifuddin Amir. (2008). Usul Fiqih. Jakarta: Kencana

Waluyo, A. (2017). Kepatuhan Bank Syariah Terhadap Fatwa Dewan Syariah 
Nasional Pasca Transformasi ke dalam Hukum Positif. Inferensi. https://doi.org/10.18326/infsl3.v10i2.517-538

Widodo Sugeng. (2014). Moda Pembiayaan Lembaga Keuangan Islam, Perspektif Aplikatif. (M. Marwini, SHI, MA, Ed.) (Pertama). Yogyakarta: Kaukaba.

Yusuf, B. (2015). Human Resources Development of Sharia Banking: Phenomenological Approach. Al-Iqtishad: Journal of Islamic Economics, Vol. 7(2): 241-250. https:// doi.org/10.15408/ijies.v7i2.1701

Zainan, N. I., \& Ismail, A. G. (2013). Musyarakah Mutanaqisah: Isu dan Cabaran, Kesan Terhadap Pembangunan Ekonomi. Prosiding Persidangan Kebangsaan Ekonomi Malaysia Ke VIII, 407. Universiti Kebangsaan Malaysia. 